\title{
Girlhood Studies in Post-Socialist Times
}

\author{
Olga Zdravomyslova and Elena Iarskaia-Smirnova
}

\section{$\cos 80$}

Girls born between the late 1990s and the early 2000s in the countries of the former USSR and Eastern Europe are fast entering into a particular kind of social life. In contrast to previous generations of girls born and bred under communist regimes, this post-socialist generation has access to the Internet, social networks, and global mass culture. They speak in a different voice, and they raise new issues and seek answers to them.

The conception of post-socialism can help to interpret the diversified processes of the radical transformations unfolding in the space of the former USSR as well as in Central and East Europe. It can help address, too, the questions about how changing gender relations are shaping and are being shaped by post-socialist marketization and liberalization (see True 2003). After the so-called velvet revolutions in Europe at the end of the 1980s and especially after the collapse of the USSR in 1991, the transformations of the post-Communist societies were discussed almost exclusively in terms of the transition from Soviet totalitarianism to Western democracy (see Herrschel 2007). Since the early 2000s a set of new challenges and opportunities has encouraged a more nuanced view. The concept of transition to Western democracy has been revised (Rose 2009) and the peculiarities of post-socialist societies, and the multiple ruptures and continuities with socialism have been revealed, including the specificities of gender policies and arrangements (see Gal and Kligman 2000).

From this perspective post-socialist transformation is one of the possible responses to the challenge of modernity coming from the developed West. Despite a variety of economic, political, and social scenarios, each country in its post-socialist reality is aiming to realize a synthesis of Western experience and local or traditional elements (Suny 2002). This process is accompanied by the rise of the role of religion, the dramatic increase in the traditionalist and, at times, fundamentalist, trends expressed in the toughening of clashes between anti-Western conservatives and pro-Western 
modernists. Politics and ideology, the public sphere, and everyday life become the field of this struggle. Coming of age in such circumstances has become a real quest. Life choices and styles proliferate, and conflicts relating to values arise within families and between and among generations. Girls become socialized into multiple and seemingly incompatible normative systems; they search for, and try on, various identities while making difficult choices between patterns, values, and roles.

From the end of the 1980s until the end of the 1990s, as sociologist Svetlana Aivazova argues, "The proclamation of democratic ideals and the rise of the free market were accompanied by a spread in the discourse of women's rights and gender equality (for example, among independent women's movements)" (2008: 29, our translation). Alongside but in contrast to it, according to Lynne Attwood, "debates among educators, psychologists and social scientists about the formation of social and sexual identity have clearly demonstrated that the new sexual culture which has replaced the official puritanism of the Soviet period has not challenged but has reinforced many of the old stereotypes of masculinity and femininity" (1996: 119).

In the 2000s, the issues relating to the fertility rate, the family, gender roles, and gender identity have become the focus of a politicized and aggressive discourse in which the ideology of the protection of traditional values is set against the ideas of the emancipation of women, and gender equality (Concept of the State Family Policy of the Russian Federation 2013). The conviction in 2012 of members of the girls' punk group Pussy Riot, accused of hooliganism after their protest action in the Cathedral of Christ the Savior in Moscow, showed the rise of the authority of the Church in defining the rules of public behavior and moral norms for girls and women. During the trial of the Pussy Riot performers "the prosecutor argued that a 'gross violation of public order, showing clear contempt of society [was] clearly established.' However, Judge Syrova deemed it necessary to find an even stronger argument. According to her, the act of hooliganism was a result of the defendant's passion for feminism, which was asserted in opposition to the principles of equality guaranteed by the law and the religious norms traditionally regulating women's situation" (Kondakov 2014: 169, our translation). The ideology of protection for traditional values is legitimized in the 2013 Federal Law on the Ban of Propaganda of "Non-Traditional Sexual Relations" among Minors. By firmly linking the "non-traditional" to homosexual relationships the Law attaches clearly negative connotations to the concept of the non-traditional and to that of tolerance, driving everything related to them out of the arena of public discussion. 
Dominant public discourse, as represented in the mass media and on the Internet, condemns feminism and demonstrates an over-sensitive or even aggressive reaction to the growing visibility and agency of girls; this is taken by the public as a challenge. At the same time, since at least the 1990s, according to sociologists Mariia Kotovskaia, and Natal'ia Shalygina, girls and young women have "clearly demonstrated a tendency towards free experimentation in sex-rule behavior, in effect allowing boys only the opportunity to react. They have a strong sense of competitiveness and seek leadership roles" (1996: 122).

Today's post-socialist societies, experiencing, as they do, an evident cultural and political conflict between traditionalists and modernists, are increasingly concerned about the ways in which girls move into womanhood; this sometimes falls into moral panic. Recently, public discourse has been increasingly supportive of the idea of the inviolability of so-called ideal (read: traditional) femininity. Staying away from the discussion of new models of femininity actively embraced by girls and young women, public opinion is reluctant to recognize their legitimacy. Thus, gaps between and among girls from different regional, ethnic, and class groups are increasing dramatically. This makes it more and more important that, in Girlhood Studies, we view girlhoods from the perspective of intersectionality (Choo and Ferree 2010). The plurality of practices and images of girlhood should be taken into account in the new agenda of Girlhood Studies in Russia and other countries that have a socialist past and in which social inequality is rising given the ways in which double gender standards increasingly influence people's choices and the realities of everyday life. For many, girls' inequality means that they must overcome multiple social and cultural barriers in their lives. The identities of gender, age, and culture intersect and "impact upon the girl-child's experience of the world" (Amoah 2007: 2). However, until recently this issue has not been adequately reflected in academic debates in Russia.

Despite the fact that the discipline of gender studies in the post-socialist countries emerged in the early 1990s and has already become a multidisciplinary research area, Girlhood Studies has always been fragmented and dispersed in this area of investigation: girls are still very rarely seen by researchers as belonging to a separate and peculiar age and gender group. For example, the best known Russian study on girlhood (Borisov 2002) represents a description and classification of games, hobbies, and leisure activities, and focuses on the traditional cultural practices that have played an important role in the construction of girls' identity. It can be safely said that Girlhood Studies has not grown beyond the boundaries of traditional 
descriptive approaches in which girlhood is viewed as a closed, undeveloped world, a kind of pre-life in which girls are denied the right to reflect or act.

We consider Girlhood Studies to be an innovative theoretical approach to, and a significant sphere of, international interdisciplinary dialogue on girlhood. The articles collected in this issue represent a broad range of themes and approaches. This issue opens with articles that focus on the representations of girls as indicative of societal change and transition.

Ana Bento-Ribeiro explores in her article, "Bodies in Transition: Girlhoods in Post-Communist Balkan Cinema," how girl teenagers are represented in post-Communist Balkan cinema. According to her, girls of newly capitalist societies construct identities permeated by a specific construction of gender based on changing ways of consumption, and on redefining the relationship of these societies to the West. In analyzing two films about the coming of age of Balkan girls from different backgrounds, urban and rural, Bento-Ribeiro argues that these girls' bodies in transition can be read as metaphors for post-Communist countries in transition.

In "The Construction of Girls' Femininity through the Ukrainian TV Show The Queen of the Ball," Tetiana Bulakh investigates how, in the transition from socialism to post-socialism, gender is constructed as a performative act by this make-over TV show, and how this process corresponds to post-socialist views of beauty and femininity. Bulakh's focus is on how The Queen of the Ball furthers the belief that girls' empowerment is based on the notion that living out stereotypically flawless femininity is a way of gaining power, success, and social advantage.

Olga Boytsova and Elena Mishanova present the results of their research on children's fashion in their article, "The Proper Dress Length for Little Girls? Soviet Taste, Girls Innocence and Children's Fashion in Contemporary Russia." With its focus on what counts as girls' innocence, these authors, in comparing what they describe as Soviet taste and the new Western way of dressing girls, argue that innocence is "constructed through clothing" so that the ways in which girls are dressed represent a visual way of speaking about them as well as about society.

Judith Inggs, in "Fictional Girls in Transition during Perestroika," establishes that the demand for new fictional role models of strong agentic girls for the new generation of perestroika children and young adults was not met. In a detailed analysis of stories written for children and young adults from the late 1980s and early 1990s, she demonstrates that the old stereotypes of girls as "weak and ineffectual" have been perpetuated in fiction which still insists on having strong male heroes. 
Two contributors then examine issues related to the normativity of girlhood in transition to adulthood. Yulia Gradskova, in "Organizing Girls' Groups for a Better Future: Local and Global Challenges and Solutions," explores the normativity of girlhood in contemporary Russia by focusing on the Nordic-Russian co-operation project that runs group workshops for girls. She demonstrates that, compared with Nordic ones, Russian girls get rather contradictory messages about acceptable gender roles. Gradskova concludes that, despite the fact that girls in Russia today are experiencing many more global influences than did previous generations, they remain committed to the traditional gender norms inherited from the Soviet era that have been reinforced during the post-socialist period.

In "Mapping Motherhood: Girls as Mothers in Contemporary Russia," Nadya Nartova demonstrates another aspect of the construction of the normativity of girlhood. In discussing the discursive work that girls who have had babies before the age of 18 do in relation to their maternal practices as well as to normalize teenage motherhood, she questions the dominant cultural representations about good motherhood in relation to age and experience.

Finally, two contributors, both drawing on a set of in-depth semi-structured interviews with girls and boys, examine the ways in which girls interpret themselves. Elena Omelchenko in her article, "Between us Girls: On Girls' Interpretations of Sexuality," looks at how Russian girls who are learning to become blue-collar or pink-collar professionals see the significance, or lack of it, of their first sexual experience. She examines the ways in which girls exercise girl-power in this context of intimacy with a partner and concludes that "girls' sexuality remains a guarded space of freedom."

Elvira Arif discusses in her article, "Fighting is not Pretty': Interpreting the Experience of Self-Defense in Girls' Fights," the issues of girls' security in urban space in connection with their defense against physical assault. In a discussion of girls' narratives about "their conception of the image of the body," she points out that while for girls fighting is seen to be in conflict with dominant gender discourse, girls are able to normalize their experience of self-defense.

This issue of Girlhood Studies came about in the wake of the successful academic discussion about Girlhood Studies that was organized with the international cooperation of the International Foundation for Socio-Economic and Political Studies (The Gorbachev Foundation), the Journal of Social Policy Studies of the Higher School of Economics, Moscow, Girlhood Studies: An Interdisciplinary Journal, and the Heinrich Böll Foundation in 
Russia. We do believe that our joint initiative opens up a new area of research and public discussion, thinking, and agency.

$\cos$

Olga ZDRAVOMYSLOVA is a sociologist, the Executive Director of the International Foundation for Socio-economic and Political Studies (The Gorbachev Foundation) and the Vice President of Raisa Gorbacheva Club, and is on the Editorial Board of Girlhood Studies: An Interdisciplinary Journal. Her areas of interest include gender, girlhood studies, the socialization of youth, and post-socialist transformation.

Elena IARSKaIA-Smirnova is a professor at the National Research University Higher School of Economics, Moscow, and the Editor-in-Chief of the Journal of Social Policy Studies. Her areas of interest include the sociology of professions, social policy, gender, and disability studies.

\section{Acknowledgments}

Serving as Guest Editors of this issue has been an extremely valuable experience and privilege. We are grateful to the contributors and reviewers of these articles. We also thank Bodil Formark who provided a Nordic team of reviewers for this issue. We would like to express our deep gratitude to managing editor Ann Smith for her excellent editing, supportive mentorship of authors, positive criticism, patience, and understanding. It was real pleasure to work with her. We are grateful to Claudia Mitchell for giving us this opportunity and greatly appreciate her support of our project, her enthusiasm, openness to discussion, and her readiness to find solutions to problems.

\section{References}

Aivazova, Svetlana. 2008. Rossiiskie vybory: gendernoie prochtenie. Moskva: Institut soziologii RAN.

Amoah, Jewel. 2007. "The World on Her Shoulders: The Rights of the Girl-

Child in the Context of Culture \& Identity." Essex Human Rights Review 4, no. 2: 1-23. http://projects.essex.ac.uk/ehrr/V4N2/amoah.pdf (accessed 29 January 2015). 
Attwood, Lynne. 1996. "Young People, Sex and Sexual Identity." Pp. 95-120 in Gender, Generation and Identity in Contemporary Russsia, ed. Hilary Pilkington. London: Routledge.

Borisov, Sergei. 2002. Mir russkogo devichestva: 70-90 gody XX veka. Moskva: Ladomir.

Choo, Hae Yeon, and Myra Marx Ferree. 2010. "Practicing Intersectionality in Sociological Research: A Critical Analysis of Inclusions, Interactions, and Institutions in the Study of Inequalities." Theory and Society 28, no. 2: 129-149.

Gal, Suzan, and Gail Kligman. 2000. The Politics of Gender after Socialism: A Comparative-Historical Essay. Princeton, NJ: Princeton University Press.

Federal'nyi zakon Rossiiskoi Federatsii ot 29 iiunia 2013 g. No: 135-FZg. Moskva. http://www.rg.ru/2013/06/30/deti-site-dok.html (accessed 1 February 2015).

Herrschel, Tassilo. 2007. Global Geographies of Post-Socialist Transitions: Geographies, Societies, Policies. London: Routledge.

Kondakov, Alexandr. 2014. Proklinaya feminizm v zale suda: konstruirovaniye gendernogo grazhdanstva v protsesse nad Pussy Riot. Neprikosnovennyi zapas 1, no. 93: 156-175.

Kontseptsiia gosudarstvennoy semeinoy politiki Rossiyskoy Federatsii na period do 2025 goda (obshchestvennyi proiekt). 2013. http://www.komitet2-6.km. duma.gov.ru/site.xp/050049124053056052.html (accessed 1 February 2015).

Kotovskaia Mariia, and Natal'ia Shalygina. 1996. "Love, Sex and Marriage-the Female Mirror: Value Orientations of Young Women in Russia” Pp. 121-131 in Gender, Generation and Identity in Contemporary Russia, ed. Hilary Pilkington. London: Routledge.

Rose, Richard. 2009. Understanding Post-Communist Transformation: A Bottom Up Approach. London: Routledge.

Suny, Ronald. 2002. "Socialism, Post-Socialism, and the Appropriately Modern: Thinking About the History of the USSR." Ab Imperio 2, no. 9: 19-54.

True, Jacqui. 2003. Gender, Globalization, and Postsocialism: The Czech Republic after Communism. New York: Columbia University Press. 